\title{
In vivo action of IL-27: reciprocal regulation of Th17 and Treg cells in collagen-induced arthritis
}

\author{
Su-Jin Moon ${ }^{1,5}$, Jin-Sil Park ${ }^{2,5}$, Yu-Jung Heo², Chang-Min Kang ${ }^{2}$, Eun-Kyung Kim², Mi-Ae Lim², \\ Jun-Geol Ryu' ${ }^{2}$, Seong Jeong Park ${ }^{3}$, Kyung Su Park ${ }^{2,4}$, Young-Chul Sung ${ }^{3}$, Sung-Hwan Park ${ }^{2,4}$, Ho-Youn Kim²,4, \\ Jun-Ki Min ${ }^{1,6}$ and Mi-La Cho ${ }^{2,6}$
}

Interleukin (IL)-27 is a novel cytokine of the IL-6/IL-12 family that has been reported to be involved in the pathogenesis of autoimmune diseases and has a pivotal role as both a pro- and anti-inflammatory cytokine. We investigated the in vivo effects of IL-27 on arthritis severity in a murine collagen-induced arthritis (CIA) model and its mechanism of action regarding control of regulatory T (Tregs) and IL-17-producing T helper 17 (Th17) cells. IL-27-Fc-treated CIA mice showed a lower severity of arthritis. IL-17 expression in the spleens was significantly decreased in IL-27-Fc-treated CIA mice compared with that in the CIA model. The Th17 population was decreased in the spleens of IL-27-Fc-treated CIA mice, whereas the CD4 ${ }^{+}$CD25 $5^{+}$Foxp3 ${ }^{+}$ Treg population increased. In vitro studies revealed that IL-27 inhibited IL-17 production in murine $\mathrm{CD} 4{ }^{+} \mathrm{T}$ cells, and the effect was associated with retinoic acid-related orphan receptor $\gamma \mathrm{T}$ and signal transducer and activator of transcription 3 inhibition. In contrast, fluorescein isothiocyanate-labeled forkhead box P3 (Foxp3) and IL-10 were profoundly augmented by IL-27 treatment. Regarding the suppressive capacity of Treg cells, the proportions of CTLA-4 ${ }^{+}$(cytotoxic T-lymphocyte antigen 4), PD-1 ${ }^{+}$(programmed cell death protein 1) and GITR ${ }^{+}$(glucocorticoid-induced tumor necrosis factor receptor) Tregs increased in the spleens of IL-27-Fc-treated CIA mice. Furthermore, in vitro differentiated Treg cells with IL-27 exerted a more suppressive capacity on T-cell proliferation. We found that IL-27 acts as a reciprocal regulator of the Th17 and Treg populations in CD4 ${ }^{+}$cells isolated from healthy human peripheral blood mononuclear cells (PBMCs), as well as from humans with rheumatoid arthritis (RA) PBMCs. Our study suggests that IL-27 has the potential to ameliorate overwhelming inflammation in patients with RA through a reciprocal regulation of Th17 and Treg cells.

Experimental \& Molecular Medicine (2013) 45, e46; doi:10.1038/emm.2013.89; published online 4 October 2013

Keywords: collagen-induced arthritis; interleukin-27; interleukin-17-producing T cells; regulatory T cells; rheumatoid arthritis

\section{INTRODUCTION}

Interleukin (IL)-27 is a member of a heterodimeric cytokine produced by antigen-presenting cells (APCs), including monocytes and dendritic cells. It belongs to the IL-12 cytokine family, which also includes IL-23 and IL-35. ${ }^{1}$ IL-27 is composed of the Epstein-Barr virus-induced gene 3 (EBI3) and 28 subunits, and has been demonstrated to have a pivotal role as both a pro- and anti-inflammatory cytokine. ${ }^{2}$ A recent report by
Wojno et al. ${ }^{3}$ showed that IL-27 transgenic mice exhibited a systemic inflammatory condition accompanied by an increased percentage of activated $\mathrm{T}$ cells and an elevated interferon (IFN) $-\gamma$ level. In that study, IL-27 transgenic mice lacked regulatory $\mathrm{T}$ (Treg) cells in lymphoid organs, suggesting that the inappropriate inflammation was caused by a Treg deficiency. Regarding the T helper type 1 (Th1) cells, IL-27 is thought to mediate the proinflammatory response by

\footnotetext{
${ }^{1}$ Bucheon St Mary's Hospital, Division of Rheumatology, Department of Internal Medicine, College of Medicine, The Catholic University of Korea, Bucheon City, Gyeonggi-do, Republic of Korea; ${ }^{2}$ Rheumatism Research Center, Catholic Research Institute of Medical Science, The Catholic University of Korea, Seoul, Republic of Korea; ${ }^{3}$ Division of Molecular and Life Sciences, POSTECH Biotech Center, Pohang University of Science and Technology, Pohang, Republic of Korea and ${ }^{4}$ Division of Rheumatology, Department of Internal Medicine, School of Medicine, The Catholic University of Korea, Seoul, Republic of Korea

${ }^{5}$ These authors contributed equally to this work.

6These authors contributed equally to this work.

Correspondence: J-K Min, Bucheon St Mary's Hospital, Division of Rheumatology, Department of Internal Medicine, College of Medicine, The Catholic University of Korea, 327 Sosa-ro, Wonmi-gu, Bucheon City, Gyeonggi-do 420-717, Republic of Korea.

E-mail: min6403@catholic.ac.kr

or Professor Mi-La Cho, Rheumatism Research Center, Catholic Institutes of Medical Science, The Catholic University of Korea, 505 Banpo-dong, Seoul, Seocho-gu 137-040, Republic of Korea.

E-mail: iammila@catholic.ac.kr
}

Received 28 September 2012; revised 3 July 2013; accepted 10 July 2013 
modulating the early stage of Th1 cell differentiation via induction of the IL-12 receptor $\beta 2$ expression. ${ }^{4}$ On the contrary, IL-27R ${ }^{-1-} \mathrm{CD} 4{ }^{+} \mathrm{T}$ cells produce more IL-2 than wild-type cells during Th1 differentiation, suggesting that IL-27 has anti-inflammatory properties. ${ }^{5}$ Taken together, the in vivo and in vitro consequences of the response of immune cells to IL-27 appear to be a complicated and a complex problem.

Rheumatoid arthritis (RA) is a systemic inflammatory disease characterized by hyperplasia of the synovial tissue and progressive destruction of joint structure (cartilage, bone and ligament). If inflammation is uncontrolled, the chronic progression of RA could result in complete ankylosis and subsequent loss of joint function. The pathogenesis of RA is a complex process mediated by an interdependent network of cytokines, prostanoids and proteolytic enzymes. ${ }^{6}$ Representative proinflammatory cytokines include tumor necrosis factor, IL-1 and IL-6, the levels of which are increased in patients with RA compared with other forms of arthritis. ${ }^{7,8}$ However, relatively few reports have investigated populations or the biological function of the anti-inflammatory cytokines such as IL-27, until now. One recent study by Niedbala et al. ${ }^{9}$ determined that IL-27 is expressed by the synovial tissues in RA, and short-term administration of IL-27 at the onset of arthritis significantly attenuated the severity of the disease using a murine model of collagen-induced arthritis (CIA), suggesting protective roles for IL-27 in the pathogenesis of RA. ${ }^{9}$ However, other studies have disagreed with the in vitro function of IL-27 when studied in humans. For instance, Wong et al. ${ }^{10}$ demonstrated that high concentrations of IL-27 induced the production of IL-6 and inflammatory chemokines from fibroblast-like synoviocytes of RA.

Several in vivo animal models and in vitro human studies have suggested that IL-17-producing T helper (Th17) cells can be considered a decisive mediator of RA with respect to joint inflammation and enhanced osteoclastogenesis. ${ }^{11,12}$ Along with Th17, Treg cells have been highlighted in both the pathogenesis of RA as well as in therapeutic strategies for the treatment of RA. Treg cells are pivotal immune cells and are a distinct regulatory lymphocyte that functions through the suppression of harmful autoimmune $\mathrm{T}$ cells in the periphery. ${ }^{13}$

We recently investigated the effects of IL-27 in a murine model and demonstrated that IL-27-Fc-injected CIA showed lower arthritis indices and fewer osteoclastogenesis. ${ }^{14}$ Furthermore, the in vivo effect of IL-27 in the aspect of modulation of Th17 and Treg populations was examined in our present study. To the extent of our knowledge, this is the first study that has $\mathrm{s}$ hown the anti-inflammatory property of IL-27 through reciprocal regulation of Th17 and Treg populations, which may contribute to its antiarthritic effects.

\section{MATERIALS AND METHODS}

\section{Animals}

Four- to 6-week-old male DBA/1J mice were purchased from SLC (Shizuoka, Japan) and were housed in polycarbonate cages and fed with standard mouse chow (Ralston Purina, St Louis, MO, USA) and water ad libitum. To confirm the in vivo effect of IL-27 in a CIA model, the mice were randomized into two groups of six animals each. All experimental procedures were examined and approved by the Animal Research Ethics Committee of the Catholic University of Korea.

\section{Plasmid construction}

Codon-optimized mouse IL-27p28 (GenBank: 145636), IL-27EBI3 (GenBank: 015766) and the Fc region of non-cytolytic $m I g G 2 a^{15}$ genes were synthesized using codons for mammalian cell expression by GeneScript (Piscataway, NJ, USA) and cloned into the pUC57 plasmid. Codon-optimized mouse IL-27p28 $\left(m p 28^{c o}\right)$, the internal ribosomal entry site (IRES) of the encephalomyocarditis virus, mouse $I L-27 E B I 3\left(m E B I 3^{c o}\right)$ and non-cytolytic Fc $(\mathrm{mFcm})$ were linked in a tandem, unidirectional arrangement. The expression cassettes of $m p 28^{c o}-I R E S-m E B I 3^{c o}$ and $m p 28^{c o}-I R E S-m E B I 3^{c o}-m F c m$ were inserted into the pGX10 vector, ${ }^{16}$ using the EcoRV/NcoI or EcoRV/NotI restriction enzyme sites to generate the $p G X 10-m p 28^{c o}-I R E S-m E B I 3^{c o}$ and $p G X 10-m p 28^{c o}-I R E S-E B I 3^{c o}-m F c m$ constructs.

\section{Induction of CIA and administration of IL-27}

To induce CIA in DBA1/J mice, type II collagen (CII) was dissolved overnight in $0.1 \mathrm{~N}$ acetic acid $\left(4 \mathrm{mg} \mathrm{ml}^{-1}\right)$ with gentle rotation at $4{ }^{\circ} \mathrm{C}$. The mice were injected intradermally at the base of the tail with $100 \mu \mathrm{g}$ CII emulsified 1:1 $\left(\mathrm{wV}^{-1}\right)$ in complete Freund's adjuvant (Chondrex, Redmond, WA, USA). The hydrodynamic gene delivery via tail vein injection is a highly efficient and simple procedure to deliver plasmid DNA into small animals. Eight days after the CII immunization, the mice were rapidly injected intravenously with $100 \mu \mathrm{g}$ IL-27-Fc in $2 \mathrm{ml}$ saline within $5 \mathrm{~s}$. To enhance the efficiency of gene therapy in vivo, subsequent intramuscular electrical stimulation (electroporation) was used. Intramuscular electroporation gene transfer is a highly effective method for increasing gene expression by creating transient pores in the cell membrane through which the plasmids can enter the cells. ${ }^{17}$ Eight days after the hydrodynamic injection, the same mice were injected intramuscularly with $100 \mu \mathrm{g}$ IL-27-Fc in the left leg by electroporation. The intramuscular injection was performed with a 31-G insulin syringe. After 2 days, they were injected intramuscularly with $100 \mu \mathrm{g}$ IL-27-Fc in the right leg by electroporation.

\section{Immunohistochemical analysis of IL-27}

Five-micrometer sections of RA and synovium were fixed in $4 \%$ paraformaldehyde, decalcified in ethylenediaminetetraacetic acid -containing bone decalcifier, embedded in paraffin and sectioned. The tissues were incubated with the primary antibody to IL-27 (R\&D Systems, Minneapolis, MN, USA) overnight at $4{ }^{\circ} \mathrm{C}$. The tissues were then incubated with a biotinylated secondary antibody and a streptavidin-peroxidase complex for $1 \mathrm{~h}$.

\section{Confocal microscopy of immunostaining}

Spleen tissues were snap frozen in liquid nitrogen and stored at $-70^{\circ} \mathrm{C}$. Tissue sections $(7 \mu \mathrm{m})$ of the spleens were fixed in acetone and stained for Treg cell marker stain using phycoerythrin (PE)- or fluorescein isothiocyanate (FITC)-labeled forkhead box P3 (Foxp3), peridinin chlorophyll-labeled anti-CD4, APC-labeled anti-CD25, FITC-labeled programmed cell death protein 1 (PD-1), biotin antimouse glucocorticoid-induced tumor necrosis factor receptor (GITR) (all from eBioscience, San Diego, CA, USA), PE-labeled cytotoxic T-lymphocyte antigen 4 (CTLA-4) and second streptavidin-FITC 
(both from BD Bioscience, Oxford, UK) antibody. To stain the Th17 marker, PE-labeled IL-17 antibody (eBioscience) and FITC-labeled anti-CD4 antibody were used. After incubation overnight at $4{ }^{\circ} \mathrm{C}$, the stained sections were analyzed using a confocal microscopy system (LSM 510 Meta, Carl Zeiss, Oberkochen, DE, USA). Positive cells were enumerated visually at higher magnification by four individuals.

\section{Murine cell preparation and culture}

The C57BL/6 mouse spleens were collected for cell preparation and washed two times with phosphate-buffered saline. The spleens were minced and the red blood cells were lysed with $0.83 \%$ ammonium chloride. The cells were filtered through a cell strainer and centrifuged at 1300 r.p.m. at $4{ }^{\circ} \mathrm{C}$ for $5 \mathrm{~min}$. To purify the splenic CD4 ${ }^{+} \mathrm{T}$ cells, the splenocytes were incubated with CD4-coated magnetic beads and isolated using magnetic-activated cell sorting separation columns (Miltenyi Biotec, Bergisch Gladbach, Germany). CD4 ${ }^{+} \mathrm{T}$ cells were stimulated with various stimuli such as anti-CD3 $\left(0.5 \mu \mathrm{g} \mathrm{ml}^{-1}\right.$; BD Bioscience, San Diego, CA, USA), IL-23 ( $5 \mathrm{ng} \mathrm{ml}^{-1}$; R\&D Systems) or IL-27 (10 $\mathrm{ng} \mathrm{ml}^{-1}$; R\&D Systems). To establish the Treg-polarizing condition, the $\mathrm{CD} 4{ }^{+} \mathrm{T}$ cells were stimulated with plate-bound antiCD3 $\left(0.5 \mu \mathrm{g} \mathrm{ml}^{-1}\right)$, anti-CD28 $\left(0.5 \mu \mathrm{g} \mathrm{ml}^{-1}\right)$, anti-IFN- $\gamma\left(2 \mu \mathrm{g} \mathrm{ml}^{-1}\right)$, anti-IL-4 $\left(2 \mu \mathrm{g} \mathrm{ml}^{-1}\right)$ and transforming growth factor- $\beta$ (TGF- $\beta$ ) $\left(5 \mathrm{ng} \mathrm{ml}^{-1}\right)$ for 3 days.

\section{Human cell preparation and culture}

Peripheral blood mononuclear cells (PBMCs) obtained from healthy volunteers or RA patients were isolated from buffy coats using FicollHypaque (Amersham Biosciences, Pittsburg, PA, USA) and density gradient centrifugation. $\mathrm{CD} 4{ }^{+} \mathrm{T}$ cells were isolated using a CD4 ${ }^{+}$ T-cell isolation kit (Miltenyi Biotec) according to the manufacturer's instructions. $\mathrm{CD}^{+} \mathrm{T}$ cells were plated at $1 \times 10^{6}$ cells per well in a 24-well plate and then stimulated with plate-bound anti-CD3 $\left(0.5 \mu \mathrm{g} \mathrm{ml}^{-1}\right)$ and anti-CD28 $\left(0.5 \mu \mathrm{g} \mathrm{ml}^{-1}\right)$ antibodies (both from $\mathrm{BD}$ Bioscience) with no cytokine added in the presence or absence of IL-27 $\left(10 \mathrm{ng} \mathrm{ml}^{-1}\right)$ for 3 days. To establish the Th17-polarizing condition, the $\mathrm{CD}^{+} \mathrm{T}$ cells were stimulated with plate-bound anti-CD3 $\left(0.5 \mu \mathrm{g} \mathrm{ml}^{-1}\right), \quad$ anti-CD28 $\quad\left(0.5 \mu \mathrm{g} \mathrm{ml}^{-1}\right), \quad$ anti-IFN- $\gamma$ $\left(2 \mu \mathrm{g} \mathrm{ml}^{-1}\right)$, anti-IL-4 $\left(2 \mu \mathrm{g} \mathrm{ml}^{-1}\right), \quad \mathrm{IL}-1 \beta\left(5 \mathrm{ng} \mathrm{ml}^{-1}\right)$ and IL-6 $\left(20 \mathrm{n} \mathrm{ml}^{-1}\right)$ for 3 days. All cytokines were from R\&D Systems, except for TGF- $\beta$ (Peprotech, Rocky Hill, NJ, USA).

\section{Intracellular staining and flow cytometry}

Intracellular staining was performed as described. ${ }^{18}$ The following antibodies were used for intracellular staining of the mouse cells: antiCD4- peridinin chlorophyll, anti-CD25-APC, anti-PD-1-FITC, antiGITR-biotin, anti-IL-17A-FITC, anti-Foxp3-PE or FITC (all from eBioscience), streptavidin-FITC and anti-CTLA4-PE (BD Bioscience). The following antibodies were used for intracellular staining of human cells: anti-CD4-PEcy7, anti-CD25-APC, anti-IL-10-PE (BD Bioscience), anti-Foxp3-FITC and anti-IL-17A-PE (eBioscience).

\section{Mixed lymphocyte reaction}

To examine the suppressive activity of Treg cells following IL-27 stimulation, $\mathrm{CD}^{+}{ }^{+} \mathrm{CD} 25^{+}$(peridinin chlorophyll-labeled anti-CD4 and APC-labeled anti-CD25, eBioscience) T cells were sorted (DakoCytomation MoFlo, Ely, UK) from CD4 ${ }^{+} \mathrm{T}$ cells that were stimulated with or without IL-27 $\left(10 \mathrm{ng} \mathrm{ml}^{-1}\right)$ under Treg-polarizing conditions for 3 days. Sorted $\mathrm{CD} 4{ }^{+} \mathrm{CD} 25^{+}$cells were cocultured with $\mathrm{T}$ cells and irradiated APC $(7500 \mathrm{cGy})$ at a $0.2: 1: 1$ ratio in the presence of
anti-CD3 $\left(0.5 \mu \mathrm{g} \mathrm{ml}^{-1}\right)$. During the last $16-18 \mathrm{~h}$, cells were pulsed with $1 \mu \mathrm{Ci}$ of $\left[{ }^{3} \mathrm{H}\right]$ thymidine (GE Healthcare, Little Chalfont, UK) per well. The incorporation of $\left[{ }^{3} \mathrm{H}\right]$ thymidine was determined using a Betaplate scintillation counter (Perkin-Elmer, Wellesley, MA, USA).

\section{Real-time PCR}

Gene expression was analyzed by real-time quantitative PCR. Total RNA was prepared from $1 \times 10^{6}$ cells and was extracted using TRIzol reagent (Molecular Research Center, Cincinnati, OH, USA). Two micrograms of total RNA were reverse transcribed using the Superscript Reverse Transcription system (Takara, Shiga, Japan). The levels of mRNA expression were estimated using real-time quantitative PCR with LightCycler FastStart DNA Master SYBR Green I (Takara) according to the manufacturer's instructions. The following primers were used for mouse samples: IL-17, 5'-CCTCAAAGCTCAGCGTGT CC- $3^{\prime}$ (sense) and $5^{\prime}$-GAGCTCACTTTTGCGCCAAG- $3^{\prime}$ (antisense); retinoic acid-related orphan receptor $\gamma \mathrm{T}(\mathrm{ROR} \gamma \mathrm{T}), 5^{\prime}$-TGTCCTGGG CTACCCTACTG- $3^{\prime}$ (sense) and $5^{\prime}$-GTGCAGGAGTAGGCCACATT-3' (antisense); signal transducer and activator of transcription 3 (STAT3), 5'-GACCCGCCAACAAATTAAGA-3' (sense) and $5^{\prime}$-TCGT GGTAAACTGGACACCA-3' (antisense); Foxp3, $5^{\prime}$-GGCCCTTCTCC AGGACAGA- $3^{\prime}$ (sense) and $5^{\prime}$-GCTGATCATGGCTGGGTTGT-3' (antisense); IFN- $\gamma, 5^{\prime}$-AGACATTCACAATTGATTTTATTCTTAC- ${ }^{\prime}$ (sense) and $5^{\prime}$-CCTTCCTGTAGGGTATTATTATACG- $3^{\prime}$ (antisense); IL-10, $5^{\prime}$-TCCTTAATGCAGTTTAAGGGTT- $3^{\prime}$ (sense) and $5^{\prime}$-GACAC CTTGGTCGAGCTTATT- $3^{\prime}$ (antisense); and $\beta$-actin, $5^{\prime}$-GTACGACC AGAGGCATACAGG-3' (sense), $5^{\prime}$-GATGACGATATCGCTGCGCTG$3^{\prime}$ (antisense). The amplification reactions, data acquisition and analyses were performed using the LightCycler Real-Time PCR system (Roche Diagnostics, Mannheim, Germany), and the relative levels of gene expression were normalized against $\beta$-actin.

\section{Determination of cytokine concentrations in culture supernatants}

The amounts of IL-17 and IL-10 for mouse samples and IL-17, IFN- $\gamma$ and IL-10 for human samples in the culture supernatants were measured by sandwich enzyme-linked immunosorbent assay (ELISA) (R\&D Systems). The absorbance was determined with an ELISA microplate reader at $405 \mathrm{~nm}$ (Molecular Devices, Sunnyvale, CA, USA).

\section{Statistical analysis}

Data are presented as the mean \pm standard deviation (s.d.). The Mann-Whitney $U$-test was used for comparing values between two groups. One-way analysis of variance followed by Bonferroni's post hoc test was used to compare the differences between three or more groups. To assess the Gaussian distribution and the equality of variance, the Shapiro-Wilk test and Levene test were used, respectively. The program used for the statistical analysis was the SPSS statistical software package, standard version 16.0 (SPSS, Chicago, IL, USA). $P$-values $<0.05$ (two-tailed) were considered significant.

\section{RESULTS}

The regulatory effect of IL-27 on the Th17/Treg population during CIA development

To determine whether IL-27 modulates disease severity in vivo, IL-27-Fc was administered by hydrodynamic injection into mice 8 days after CII immunization. Treatment with IL-27-Fc significantly ameliorated arthritis severity and incidence 
(Figure 1a). Therefore, we determined whether the protective effect of IL-27 in CIA occurs via modulation of the Th17 and Treg populations. CD $4^{+} \mathrm{T}$ cells were isolated from the spleens of CIA- and IL-27-Fc-treated CIA animals on week 4 after primary CII immunization. The results showed that the population of IL-17-expressing splenocytes decreased in IL27-Fc-treated CIA mice compared with that of CIA, whereas the proportion of IFN- $\gamma$ - and IL-10-expressing splenocytes did not differ between the two groups (Figure 1b). Flow cytometric analysis identified a modest expansion of $\mathrm{CD} 4{ }^{+}$ $\mathrm{CD}_{25}{ }^{+}$Foxp3 ${ }^{+}$Treg cells in the spleens of IL-27-Fc-treated CIA animals $(7.08 \%$ versus $8.39 \%$ in CIA- versus IL-27-Fctreated CIA, respectively) (Figure 1c). Confocal microscopy illustrated significantly decreased $\mathrm{CD} 4{ }^{+} \mathrm{IL}-17^{+}$cell populations (Th17 cells) in the spleens of IL-27-Fc-treated CIA

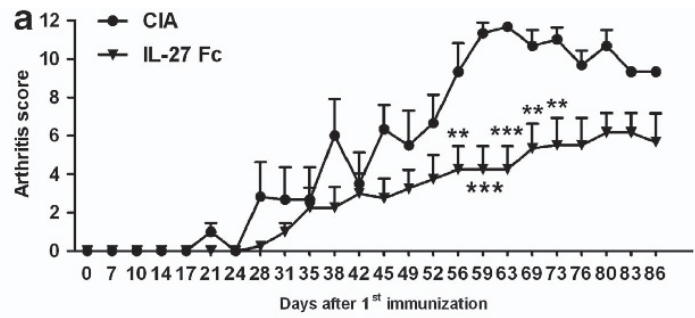

b
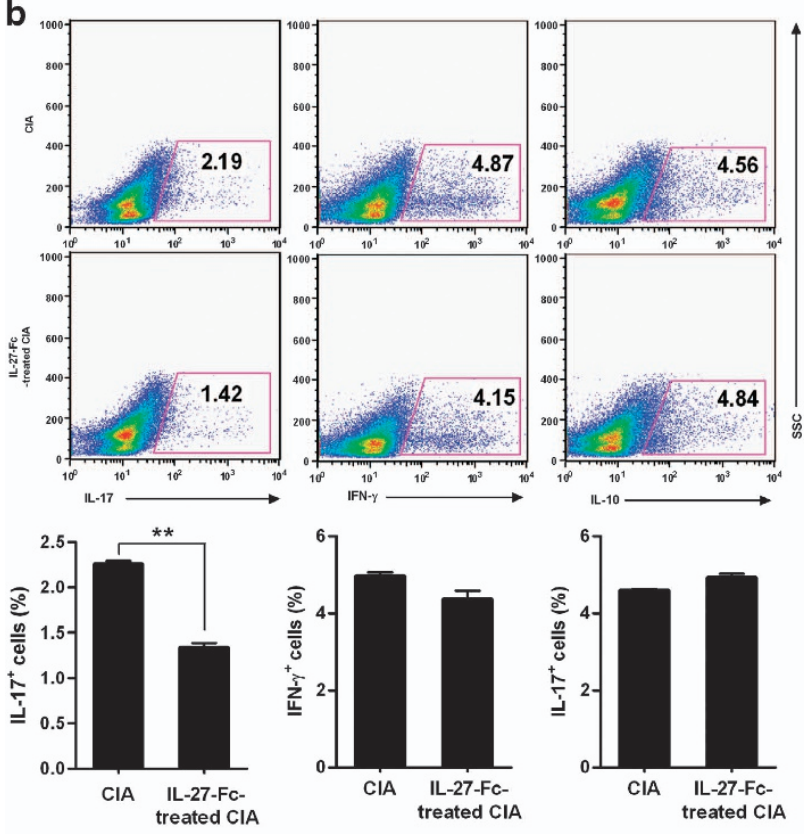

animals, whereas the $\mathrm{CD} 4{ }^{+} \mathrm{CD} 25^{+} \mathrm{Foxp} 3{ }^{+}$cell population (Treg cells) expanded (Figure 1d). The results showed that IL-27 administration in CIA animals has an anti-inflammatory role through Th17 inhibition and the reciprocal induction of Treg cells.

\section{In vitro effect of IL-27 on IL-17, IFN- $\gamma$, Foxp3 and IL-10 in murine $\mathrm{CD}^{+}{ }^{+} \mathrm{T}$ cells}

To identify the mechanism of IL-27 in autoimmune arthritis mice, in vitro experiments were conducted to verify the changes in cytokines and transcriptional factors that are implicated in Th17 and Treg cells. CD $4^{+} \mathrm{T}$ cells were isolated from normal C57BL/6 mice and then stimulated with antiCD3 in the presence or absence of IL-23 or IL-27 for 3 days. IL-23 is known to contribute to Th17 differentiation. As we
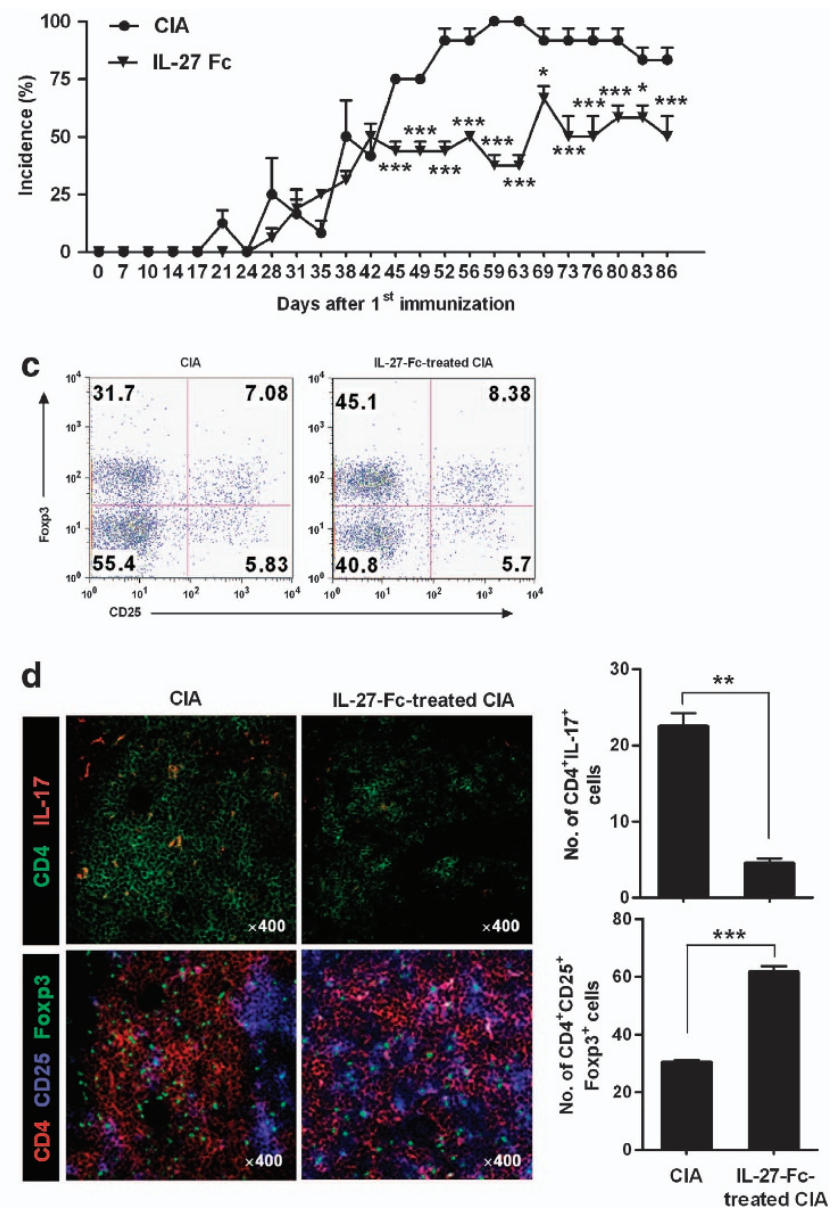

Figure 1 In vivo therapeutic effects of interelukin (IL)-27 via reciprocal regulation of T helper 17 (Th17) and Treg cells on collageninduced arthritis (CIA) development. Eight days after CIA induction, IL-27-Fc was administered by hydrodynamic intravenous injection in IL-27-Fc-treated CIA animals. Eight and 10 days thereafter, the mice received two additional injections of IL-27-FC in the muscles of both thighs by electroporation. (a) The clinical score and arthritis incidence rate of disease are shown for both CIA and IL-27-Fc-treated CIA mice over time. Data are representative of two independent experiments with six vanished animals per group (error bar, s.d.). (b) Mice were killed on day 28 after CIA induction, and the expression of IL-17, interferon (IFN)- $\gamma$ and IL-10 was analyzed on the splenocytes from each group using flow cytometry. The representative flow cytometric dot plots for each group are shown. (c) The populations of $\mathrm{CD} 4{ }^{+} \mathrm{CD} 25^{+}{ }^{+}$oxp $3^{+}$cells were analyzed by flow cytometry of the isolated splenocytes of each group. (d) Expression of $\mathrm{CD}^{+}{ }^{+} \mathrm{IL}-17^{+}$or $\mathrm{CD} 4^{+} \mathrm{CD} 25^{+}$Foxp3 ${ }^{+}$cells in the spleens of $\mathrm{CIA}$ and IL-27-Fc-treated CIA mice was analyzed by immunostaining and confocal microscopy. The data are expressed as the mean \pm s.d. (error bar) for six animals per group. Original magnification, $\times 400 .{ }^{*} P<0.05,{ }^{* *} P<0.01,{ }^{* *} P<0.001$ compared with CIA. Fosxp3, fluorescein isothiocyanate-labeled forkhead box P3. 
expected, the mRNA expression of Th17-associated molecules increased following IL-23 treatment. Interestingly, the increased mRNA levels of IL-17, ROR $\gamma$ T and STAT3 following IL-23 stimulation were diminished by IL-27 treatment, supporting the anti-inflammatory effect of IL-27 through Th17 inhibition shown in vivo above (Figure 2a). On the contrary, the mRNA level of IFN- $\gamma$ profoundly increased following IL-27 treatment but not after IL-23 treatment. IL-17 concentrations measured in the culture supernatant showed that the increased level of IL-17 following IL-23 treatment had vanished following IL-27 treatment.

Foxp3 is a key transcriptional factor known to be involved in Treg differentiation. Isolated murine $\mathrm{CD} 4{ }^{+} \mathrm{T}$ cells were stimulated with IL-27 for 3 days, and the mRNA levels were determined by real-time PCR. The results show that the mRNA levels of Foxp3 and IL-10 were significantly increased following IL-27 treatment compared with those without. The level of IL-10 as a Treg-associated cytokine was also measured in the culture supernatant. The result showed that the IL-27 treatment increased IL-10 concentrations compared with those without (Figure 2b). The cell viability did not differ between the groups (data not shown).

\section{Characterization of the suppressive functions of Treg cells in IL-27-Fc-treated CIA}

CTLA-4 and PD-1 have been revealed to augment the suppressive capacity of Treg cells on the activation of effector T cells. ${ }^{19,20}$ In addition, the expression of GITR on Tregs increases upon its activation compared with that of naive Treg. ${ }^{21}$ To ascertain whether IL-27-Fc treatment in arthritic mice influenced molecules that are implicated in the suppressive function of Tregs, the proportions of CTLA $4^{+}$, $\mathrm{PD}-1^{+}$and $\mathrm{GITR}^{+}$cells among the $\mathrm{CD} 4{ }^{+} \mathrm{CD} 25^{+}$Foxp3 ${ }^{+}$ Treg cells gated from each group of mice were identified using fluorescence-activated cell sorter (Figure 3a). The numerical analysis of $\mathrm{CD} 4{ }^{+} \mathrm{CD} 25^{+} \mathrm{Foxp}^{+}{ }^{+} \mathrm{CTLA} 4{ }^{+}, \mathrm{CD} 4{ }^{+} \mathrm{CD} 25^{+}$ Foxp $3^{+} \mathrm{PD}_{-}{ }^{+}$and $\mathrm{CD} 4{ }^{+} \mathrm{CD} 25^{+} \mathrm{Foxp}^{+}{ }^{+} \mathrm{GITR}^{+}$cells in the field was performed by confocal microscopy (Figure $3 \mathrm{c}$ ).
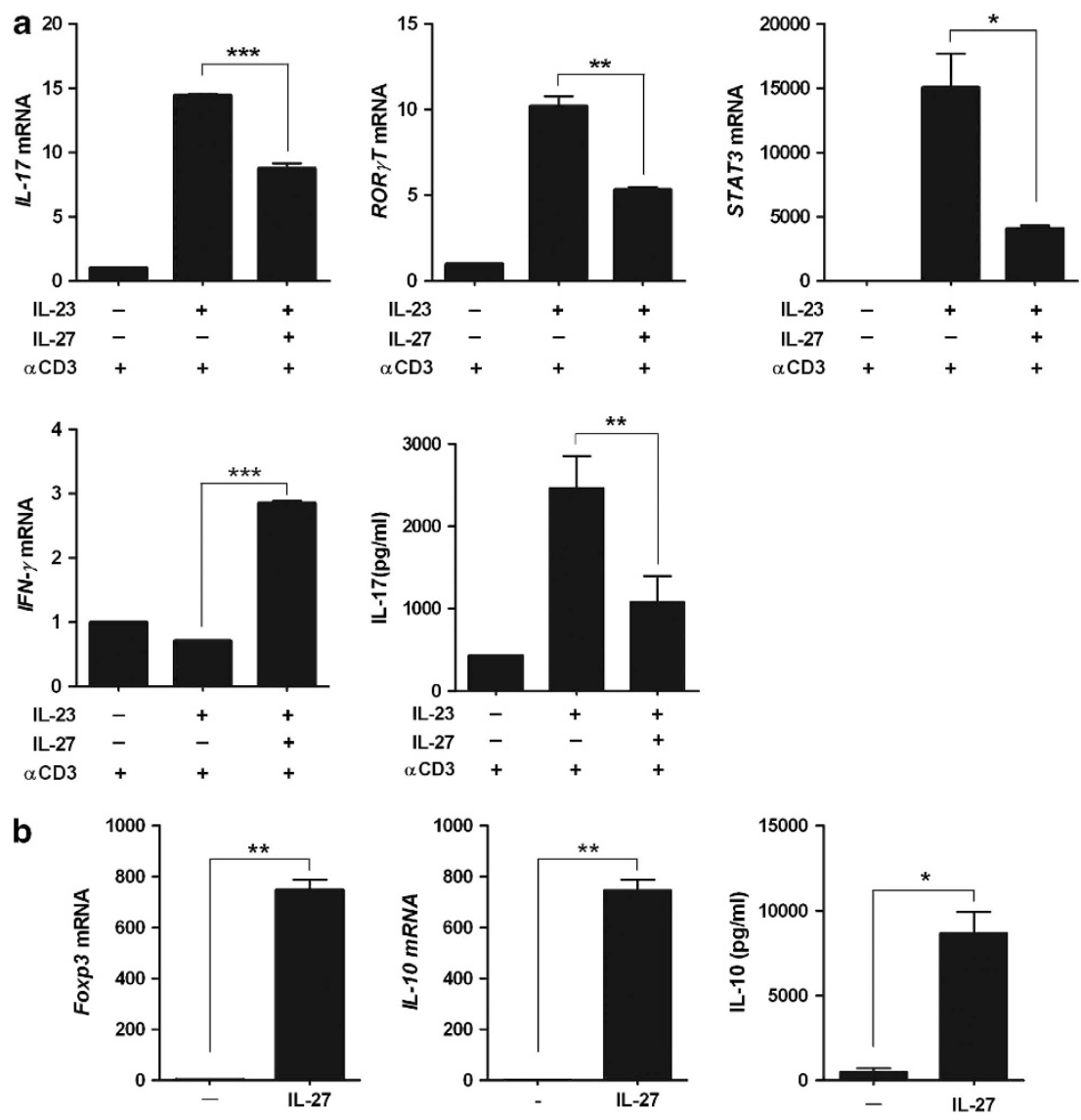

Figure 2 In vitro regulatory effects of interleukin (IL)-27. (a) Splenic CD4 ${ }^{+}$T cells were isolated from normal C57BL/6 mice and then

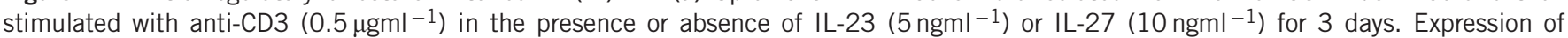
mRNA levels of IL-17, retinoic acid-related orphan receptor $\gamma \mathrm{T}$ (ROR $\gamma \mathrm{T})$, signal transducer and activator of transcription 3 (STAT3) and interferon (IFN)- $\gamma$ was analyzed by real-time polymerase chain reaction (PCR), and the IL-17 concentration of the culture supernatant was measured by enzyme-linked immunosorbent assay (ELISA). ${ }^{*} P<0.05,{ }^{*} P<0.01,{ }^{* *} P<0.001$ compared with that in the absence of IL-27. (b) Splenic CD4 ${ }^{+}$T cells isolated from normal C57BL/6 mice were cultured in the presence or absence of IL-27 for 3 days. The mRNA expression of fluorescein isothiocyanate-labeled forkhead box P3 (Foxp3) and IL-10 was determined by real-time PCR, and the IL-10 concentration in the culture supernatant was measured by ELISA. The data are expressed as the mean \pm s.d. (error bar) for three independent experiments. ${ }^{*} P<0.05,{ }^{*} P<0.01$ compared with those without. 

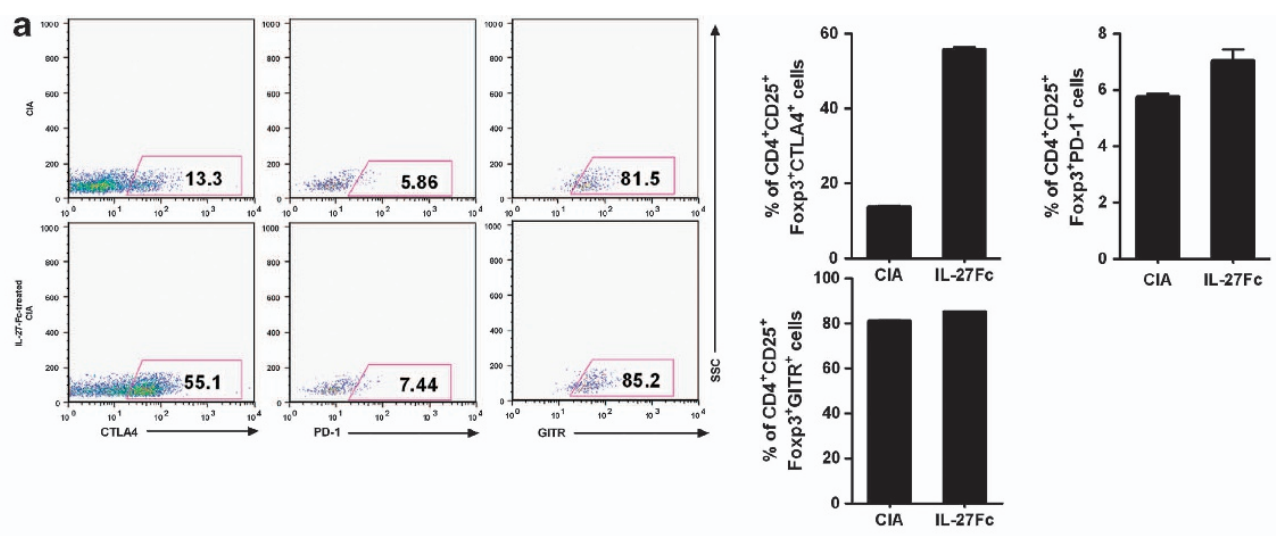

b

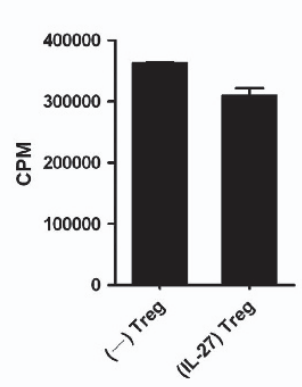

CD4: APC: Tregs (1: 1: 0.2)
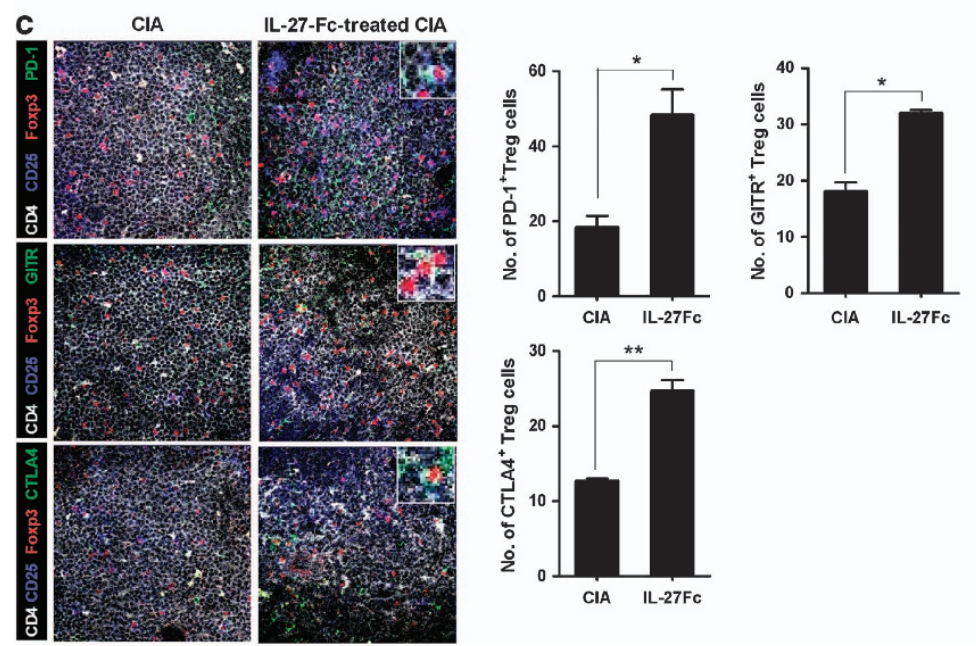

d
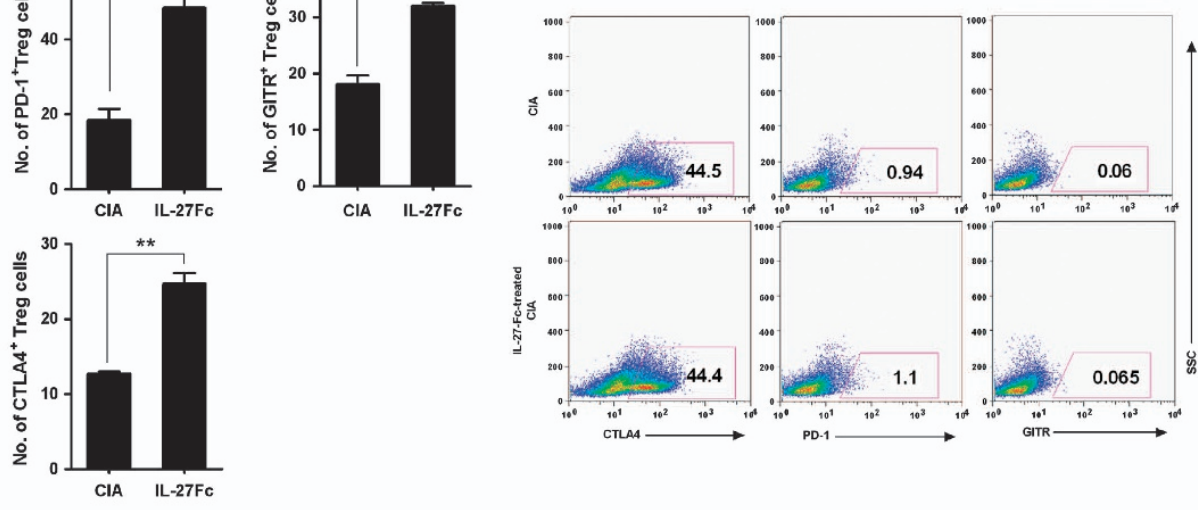

Figure 3 Changes in CTLA-4 ${ }^{+}$(cytotoxic T-lymphocyte antigen 4), PD-1 ${ }^{+}$(programmed cell death protein 1) or GITR ${ }^{+}$(glucocorticoidinduced tumor necrosis factor receptor) regulatory $T$ (Treg) populations in the spleen of interleukin (IL)-27-Fc-treated collagen-induced arthritis $(\mathrm{CIA})$. (a) The proportion of $\mathrm{CTLA}-4^{+}, \mathrm{PD}-1^{+}$or $\mathrm{GITR}^{+}$Treg cells was assessed ex vivo by intracellular flow cytometry. $\mathrm{CD} 4{ }^{+} \mathrm{CD} 25^{+}{ }^{+}$oxp $3{ }^{+}$cells were gated from splenocytes of each group of mice. Then, the expression of CTLA-4, PD-1 or GITR among these cells was identified by flow cytometric analysis. Data shown in left panel are representative of three results. (b) $C D 4+C D 25+$ regulatory $T$ cells induced under Treg-polarizing condition with or without IL-27 were cocultured with murine CD4 ${ }^{+} \mathrm{T}_{\text {cells }}$ and irradiated antigen-presenting cells (APCs) $(7500 \mathrm{cGy})$ for 3 days. T-cell proliferation was determined using the $\left[{ }^{3} \mathrm{H}\right]$ thymidine incorporation assay. Treg cells with IL-27 stimulation exerted more suppressive properties. (c) Spleens from mice of each group were examined by confocal microscopy for staining with mouse antibodies against CD4 (white), CD25 (blue), fluorescein isothiocyanate-labeled forkhead box P3 (Foxp3) (red), PD-1 (green), GITR (green) and CTLA-4 (green) (left panel) (original magnification at $\times 400$ ). The graph (right panel) represents the number of PD- $1^{+}$, GITR ${ }^{+}$or CTLA4 ${ }^{+}$Treg (represented by $\mathrm{CD} 4{ }^{+} \mathrm{CD} 25^{+}$Foxp3 ${ }^{+}$) cells that were found in the spleens of CIA- or IL-27-Fc-treated CIA. The number of PD-1+, GITR ${ }^{+}$and CTLA4 ${ }^{+}$Treg cells increased in the spleens of IL-27-Fc-treated CIA mice compared with that of CIA. The data are expressed as the mean \pm s.d. (error bar) for six mice in each group. (d) CTLA-4-, PD-1- and the GITR-expressing cell populations among effector T cells (CD4 + CD62 $\left.L^{\text {low }} \mathrm{CD} 44^{\text {high }}\right)$ were analyzed by flow cytometric analysis. In contrast to Treg cells, CTLA-4, PD-1 and GITR expression was similar between effector T cells isolated from each group. SSC, side scatter channel.

Interestingly, the proportion of PD-1-, GITR- or CTLA4positive cells among the Treg cells increased in the IL-27-Fctreated CIA spleen compared with that in the CIA mice.

Among the three molecules, the most profound difference between the two groups was in CTLA-4. In addition, we attempted to verify the effects of IL-27 on the suppressive capacity of Treg cells. Therefore, murine $\mathrm{CD} 4{ }^{+} \mathrm{T}$ cells were cultured for 3 days under Treg-polarizing conditions in the presence or absence of IL-27 $\left(10 \mathrm{ng} \mathrm{ml}^{-1}\right)$. Then, sorted $\mathrm{CD} 4{ }^{+} \mathrm{CD} 25^{+}$cells were cocultured with murine $\mathrm{CD} 4{ }^{+}$ $\mathrm{T}$ cells and irradiated APCs in the presence of anti-CD3 for
3 days. Although the difference was marginal, IL-27 treatment tended to increase the suppressive activity of Tregs on T-cell proliferation (Figure 3b).

These results suggested that Treg cells from IL-27-Fc-treated CIA mice may exert more suppressive activity, which may explain the anti-inflammatory effect of IL-27 shown in vivo. Furthermore, to ascertain whether the enhanced expressions of CTLA-4, PD-1 and GITR following IL-27 treatment were limited to Treg cells, and the levels of the three molecules on effector $\mathrm{T}$ cells $\left(\mathrm{CD} 4{ }^{+} \mathrm{CD} 62 \mathrm{~L}^{\text {low }} \mathrm{CD} 44^{\text {high }}\right)$ were determined by fluorescence-activated cell sorter. Contrary to Treg cells, the 
proportion of the molecules on effector $\mathrm{T}$ cells did not differ between the two groups (Figure 3d). Taken together, IL-27 treatment in CIA animals may augment Treg function through CTLA-4 induction. Furthermore, the effect was limited to the Treg population.

\section{IL-27 as a reciprocal regulator of human Th17 and Treg differentiation}

$\mathrm{CD}^{+} \mathrm{T}$ cells were isolated from human PBMCs of healthy volunteers and then stimulated with anti-CD3 plus anti-CD28 stimulation with no cytokine added (Th0 condition) or under Th17-polarizing condition in the presence or absence of IL-27 $\left(10 \mathrm{ng} \mathrm{ml}^{-1}\right)$ for 3 days. Flow cytometric analysis using intracellular staining was used to analyze the Th17 and Treg populations. In the Th0 condition, IL-27 treatment modestly decreased the $\mathrm{CD} 4{ }^{+} \mathrm{IL}-17^{+}$(Th17) cell population, whereas there was no significant change in the population of $\mathrm{CD} 4^{+}$ IFN- $\gamma^{+}$cells. However, the proportion of Th17 cells decreased following IL-27 treatment, whereas the $\mathrm{CD} 4{ }^{+} \mathrm{IFN}-\gamma^{+} \mathrm{T}$-cell population expanded under the Th17-polarizing condition (Figure 4a).

Regarding the Treg cells, IL-27 treatment markedly increased the $\mathrm{CD} 4{ }^{+} \mathrm{CD} 25^{+}{ }^{\mathrm{Foxp}} 3^{+}$Treg proportion under the Th17polarizing condition (Figure $4 \mathrm{~b}$ ). Furthermore, the IL-17 concentration in the culture supernatant was measured by ELISA. IL-27 treatment under Th17-polarizing conditions, not under the Th0 condition, significantly inhibited IL-17 levels in a dose-dependent manner. Reciprocally, IL-10 production in $\mathrm{CD}^{+} \mathrm{T}$ cells in Th17-polarizing conditions tended to increase following IL-27 treatment, although the difference was not statistically significant. The IFN- $\gamma$ level did not change following IL-27 treatment in either condition (Figure 4c).

In vitro effect of IL-27 on Th17 and Treg populations in RA patients and the expression of IL-27 in the RA synovium We attempted to ascertain the effects of IL-27 on Th17 and Treg differentiation in RA CD4 ${ }^{+} \mathrm{T}$ cells. $\mathrm{CD}^{+}{ }^{+} \mathrm{T}$ cells isolated from the PBMCs of RA patients were cultured in the presence of anti-CD3 plus anti-CD28 antibodies with or without IL-27 $\left(10 \mathrm{ng} \mathrm{ml}^{-1}\right)$ for 3 days. Flow cytometry assays showed that the proportions of $\mathrm{CD} 4{ }^{+} \mathrm{IL}-17^{+}$cells were reduced with IL-27 treatment, whereas the proportion of $\mathrm{CD} 4{ }^{+}$IFN- $\gamma^{+} \mathrm{T}$ cells was similar between the two groups (Figure 5a). IL-27 stimulation of CD4 ${ }^{+} \mathrm{T}$ cells of RA patients increased the percentage of $\mathrm{CD} 4{ }^{+} \mathrm{CD} 25^{+}$Foxp $3{ }^{+}$Treg cells under Th17-polarizing conditions (Figure 5b). The expression of IL-27 in RA synovium increased compared with that of osteoarthritis synovium (Figure $5 \mathrm{c}$ ). a

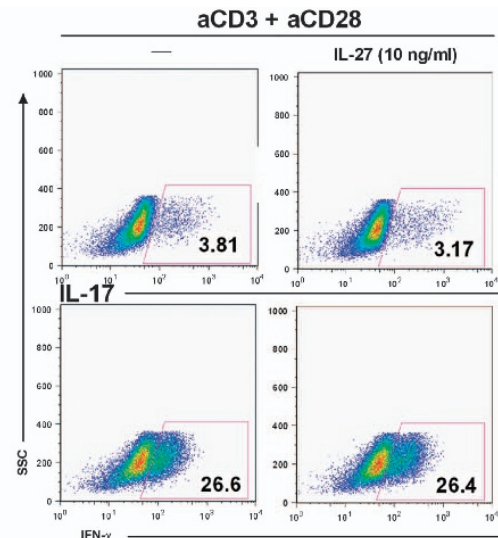

b
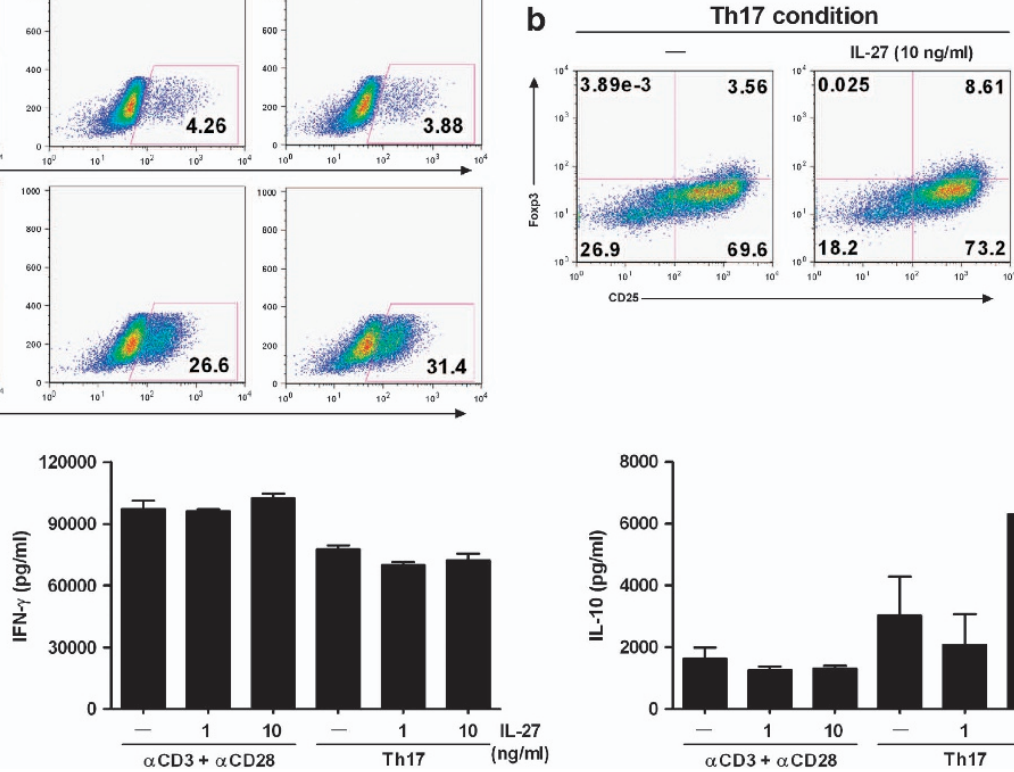

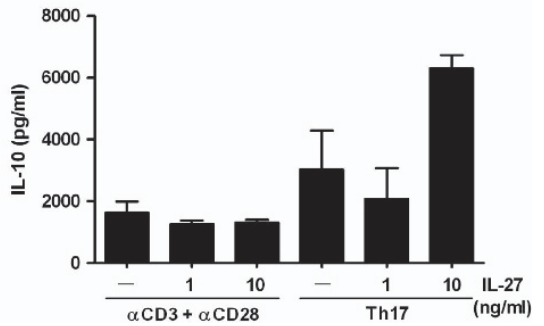

Figure 4 Reciprocal effects of interleukin (IL)-27 on the regulation of the T helper 17 (Th17) and regulatory T (Treg) lineage. $\mathrm{CD}^{+} \mathrm{T}$ cells were isolated from human peripheral blood mononuclear cells (PBMCs) of healthy subjects and stimulated with anti-CD3 plus anti-CD28 antibody stimulation with no cytokine added or in Th17-polarizing conditions in the presence or absence of IL-27. (a) After 3 days, the cells were stained intracellularly with antibodies against IL-17 and interferon (IFN)- $\gamma$ and analyzed by flow cytometry. A representative plot shows the frequencies of CD4+IL-17+ cells and CD4 + IFN- $\gamma+$ cells. (b) In vitro differentiated $\mathrm{CD} 4{ }^{+} \mathrm{CD} 25^{+}$Foxp3 ${ }^{+}$Treg cells under Th17 conditions in the presence or absence of IL-27 were identified by flow cytometric analysis. (c) The concentrations of IL-17, IFN- $\gamma$ and IL-10 in cultured supernatant from (a) were analyzed by enzyme-linked immunosorbent assay. Foxp3, fluorescein isothiocyanate-labeled forkhead box P3; SSC, side scatter channel. 
a

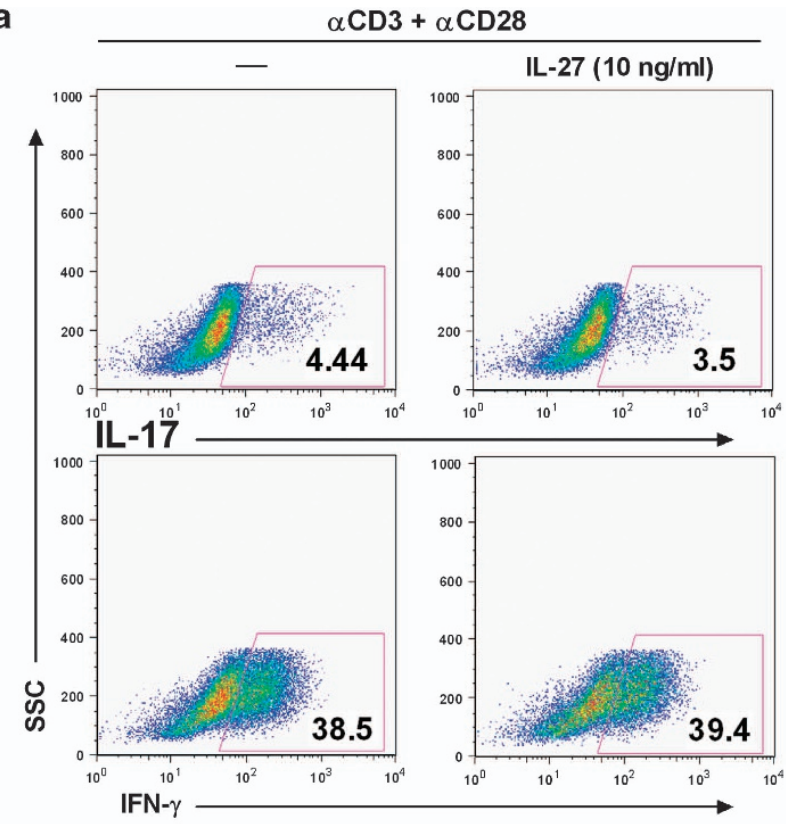

b
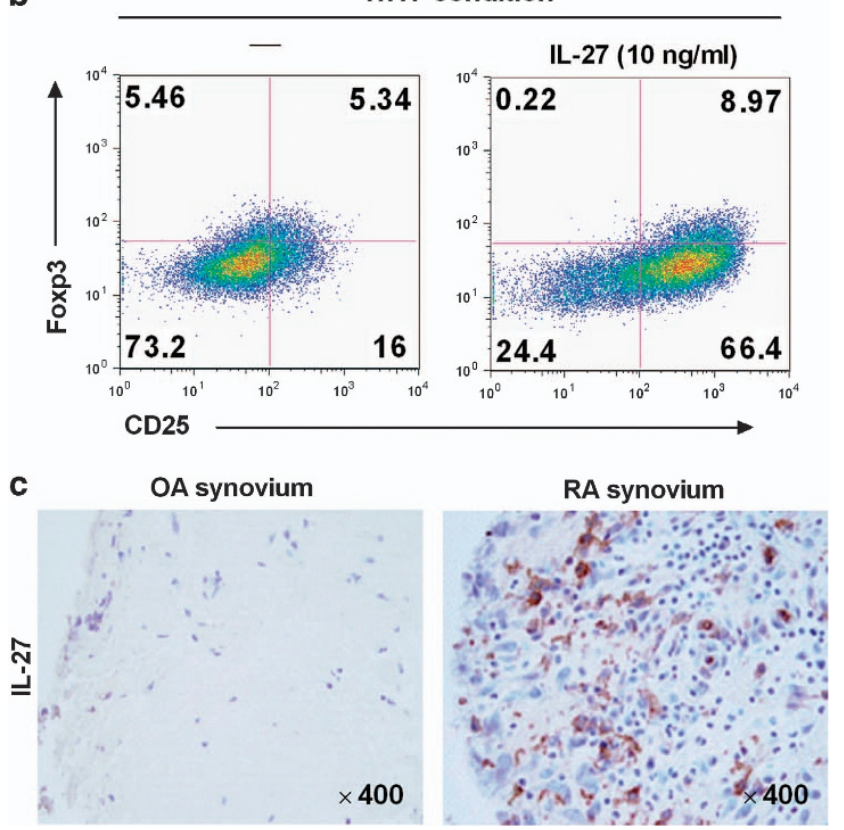

Figure 5 Effects of interleukin (IL)-27 in rheumatoid arthritis (RA) patients. (a) $\mathrm{CD}^{+}{ }^{+} \mathrm{T}$ cells were isolated from human peripheral blood mononuclear cells (PBMCs) isolated from RA patients and were cultured in the presence of anti-CD3 plus anti-CD28 stimulation with or without IL-27 for 3 days. The proportion of $\mathrm{CD} 4{ }^{+} \mathrm{IL}-17^{+}$cells and $\mathrm{CD} 4{ }^{+} \mathrm{IFN}-\gamma^{+}$cells was measured by flow cytometry using intracellular staining for IL-17 and interferon (IFN)- $\gamma$. (b) The proportion of CD4 ${ }^{+}$CD25 ${ }^{+}$Foxp $3+$ cells under T helper 17 (Th17)-polarizing conditions in the presence or absence of IL-27 was determined by flow cytometric analysis. (c) Immunohistochemical staining was used to identify the expressions of IL-27 in RA and osteoarthritis (OA) synovium (original magnification at $\times 400$ ). Foxp3, fluorescein isothiocyanate-labeled forkhead box P3; SSC, side scatter channel.

\section{DISCUSSION}

RA is a chronic inflammatory disorder that may lead to the destruction of articular structure without effective anti-inflammatory therapies such as disease-modifying anti-rheumatic drugs. Although the pathogenesis of RA remains uncertain, broken Th17/Treg balance is considered to be involved in the development as well as the progression of RA. Therefore, we conducted this study to determine whether IL-27 has a role as a reciprocal regulator in Th17 and Treg cells.

This study demonstrated the in vivo and in vitro effects of IL-27 on the Th17 and Treg cell lineages in an RA animal model and RA PBMCs. IL-27 downregulated Th17 differentiation via ROR $\gamma$ T and STAT3 inhibition and increased circulating Treg cells in vivo. Interestingly, the results show that IL-27 upregulated molecules involved in the suppressive function of Tregs, such as PD-1, GITR and CTLA4, in Treg cells in the spleens of CIA mice. Taken together, our study demonstrated that IL-27 may overwhelmingly suppress the inflammation of arthritis through the downregulation of Th17 cells via ROR $\gamma \mathrm{T}$ and STAT3 and the upregulation of the Treg cell population, as well as the augmentation of the suppressor activity of Treg cells mainly by induction of CTLA- 4 . The effects of IL-27 on the suppressor activity of Treg cells through the regulation of costimulatory molecules have not been elucidated until now.

To the best of our knowledge, IL-27 has been consistently reported to ameliorate arthritis severity and inflammation in CIA models. ${ }^{9,22,23}$ In addition, in other animal models, a IL-27 deficiency exacerbates the disease severity of experimental autoimmune encephalitis through the promotion of T-cell proliferation and Th17 cell differentiation..$^{24,25}$ Hall et al. ${ }^{26}$ also identified the anti-inflammatory capacity of IL-27 in a mouse model of toxoplasmosis. In their report, IL-27 could rescue acute pathology by promoting Treg cells at the local inflammation site. ${ }^{26}$ On the contrary, IL-27 acted in a proinflammatory manner in the pathogenesis of psoriasis in an animal model. ${ }^{27}$ In conclusion, the overall effects of IL-27 in vivo are dependent on the specific disease model.

The preferred differentiation of naive self-reactive $\mathrm{T}$ cells to Th17 effector cells occurs via a particular cytokine milieu. ${ }^{28-30}$ The proinflammatory cytokines involved in Th17 development were TGF- $\beta,{ }^{31}$ IL-2 $2{ }^{32}$ and IL-23. ${ }^{33}$ Th17 cells serve as a major source of IL-17, and both human RA and mouse models have shown that IL-17 is critical to joint inflammation and destruction. ${ }^{34}$ The continuous administration of IL-17 induces extensive inflammatory cell migration, bone erosion and cartilage degradation. ${ }^{35,36}$ IL-17 also contributes to RA chronicity through an antiapoptotic effect on resident RA fibroblast-like synoviocytes. Conversely, blocking endogenous IL-17 in a CIA model results in the suppression of arthritis. ${ }^{37}$ Currently, inspiring results were obtained in a phase I clinical trial of an IL-17 targeting biologic agent in RA patients. ${ }^{38}$ Our present study identified that in vitro administration of IL-27 reduced the IL-17 production that was associated with ROR $\gamma \mathrm{T}$ expression.

The ability of Treg cells to regulate activated effector $\mathrm{T}$ cells is also an important issue in autoimmune diseases in addition 
to an adequate number of Treg cells. The elimination or abnormality of Treg cells can cause autoimmune diseases in humans as well as animals. ${ }^{39}$ The depletion of Treg cells in CIA exacerbated the arthritis severity. ${ }^{40}$ In patients with established RA, the Treg cell population in peripheral blood and synovial fluid has been shown to be comparable with that of the controls. ${ }^{41,42}$ However, current studies have identified a defect in Treg cell function in RA patients. ${ }^{43-46}$ Treg cells from RA patients failed to inhibit the production of proinflammatory cytokines by effector $\mathrm{T}$ cells. ${ }^{43}$

CTLA4, GITR and PD-1 on the surface of Treg cells are considered to be involved in mediating the suppressive functions of mainly cell-contact-dependent mechanisms. ${ }^{47-49}$ PD-1-deficient mice showed spontaneous development of a lupus-like syndrome, including glomerulonephritis and destructive arthritis, which demonstrated that PD-1 may be involved in the prevention of autoimmune disease by maintaining peripheral self-tolerance. ${ }^{50}$ Like the effect of PD1, CTLA-4 is required for the suppressive function of Tregs during the development of those cells and during the effector phase. ${ }^{51}$ Although the ligation of GITR molecules expressed on Treg cells abrogates their suppressive activity following the activation and proliferation on effector $\mathrm{T}$ cells, the expression of GITR is upregulated upon activation compared with that on naive Treg. ${ }^{21}$ In this study, the proportions of CTLA-4-, GITRand PD-1-expressing cells among the $\mathrm{CD} 4{ }^{+} \mathrm{CD} 25^{+}$Foxp $3^{+}$ Tregs in spleens were augmented in IL-27-Fc-treated animals. We postulate that this finding may suggest the augmented suppressive capacity or activated stage of the Treg population by IL-27-Fc treatment in a murine model of arthritis.

The current data have suggested that there are two subsets of Treg cells, natural Treg (nTreg) cells and induced Treg (iTreg) cells. The nTreg cells develop in the thymus and undergo clonal expansion upon antigen exposure. The nTreg cells can migrate to the periphery and suppress autoimmunity through the inhibition of autoreactive T cells. However, iTreg cells are generated in the periphery after antigen recognition by $\mathrm{CD} 4{ }^{+} \mathrm{CD} 25^{-} \mathrm{T}$ cells. Although the biology of iTreg cells is still not well understood, they have been considered to be involved in limiting the immune response in a cytokine (IL-10 and TGF- $\beta$ )-mediated manner. In contrast, $n$ Treg cells have an immunosuppressive role via a contact-dependent mechanism such as CTLA4. In this study, treatment with IL-27 caused an increase in the IL-10 level in cultured murine $\mathrm{CD} 4^{+} \mathrm{T}$ cells, although the TGF- $\beta$ concentration did not change following IL-27 treatment (data now shown). Interestingly, our study identified that costimulatory molecules, especially in CTLA-4, are upregulated in $\mathrm{CD} 4{ }^{+} \mathrm{CD} 25^{+}$Foxp $3{ }^{+}$Treg cells. Overall, we carefully speculate that IL-27 contains an immunosuppressive property in the CIA model through the nTreg population rather than iTreg.

In summary, the results presented describe an anti-inflammatory effect of IL-27 in CIA, and IL-27 may mediate its antiarthritic effects through inhibition of Th17 differentiation via STAT3/ROR $\gamma$ T and through a reciprocal induction of Treg cells via Foxp3. In terms of suppressive function, upregulation of costimulatory molecules on Treg cells, mainly CTLA-4, may contribute to the antiarthritic effects of IL-27 shown in vivo. Our study suggests that IL-27 has the potential to control overwhelming inflammation in RA patients as a reciprocal regulator of the Th17 and Treg cell lineages.

\section{CONFLICT OF INTEREST}

The authors declare no conflict of interest.

\section{ACKNOWLEDGEMENTS}

This work was supported by a grant (A092258) from the Korea Healthcare Technology R\&D Project, the Ministry for Health and Welfare and by the Basic Science Research Program through the National Research Foundation of Korea, funded by the Ministry of Education, Science and Technology (grant numbers 2008-0059943).

1 Pflanz S, Timans JC, Cheung J, Rosales R, Kanzler H, Gilbert J et al. IL-27, a heterodimeric cytokine composed of EBI3 and p28 protein, induces proliferation of naive CD4(+) T cells. Immunity 2002; 16: 779-790.

2 Villarino AV, Huang E, Hunter CA. Understanding the pro- and antiinflammatory properties of IL-27. J Immunol 2004; 173: 715-720.

3 Wojno ED, Hosken N, Stumhofer JS, O'Hara AC, Mauldin E, Fang Q et al. A role for IL-27 in limiting T regulatory cell populations. J Immunol 2011; 187: 266-273.

4 Takeda A, Hamano S, Yamanaka A, Hanada T, Ishibashi T, Mak TW et al. Cutting edge: role of IL-27/WSX-1 signaling for induction of T-bet through activation of STAT1 during initial Th1 commitment. J Immunol 2003; 170: 4886-4890.

5 Villarino AV, Stumhofer JS, Saris CJ, Kastelein RA, de Sauvage FJ, Hunter CA. IL-27 limits IL-2 production during Th1 differentiation. J Immunol 2006; 176: 237-247.

6 Hu Y, Cheng W, Cai W, Yue Y, Li J, Zhang P. Advances in research on animal models of rheumatoid arthritis. Clin Rheumatol 2012; 32: 161-165.

7 Partsch G, Steiner G, Leeb BF, Dunky A, Broll H, Smolen JS. Highly increased levels of tumor necrosis factor-alpha and other proinflammatory cytokines in psoriatic arthritis synovial fluid. J Rheumatol 1997; 24: 518-523.

8 Steiner G, Tohidast-Akrad M, Witzmann G, Vesely M, Studnicka-Benke A, Gal $A$ et al. Cytokine production by synovial T cells in rheumatoid arthritis. Rheumatology (Oxford) 1999; 38: 202-213.

9 Niedbala W, Cai B, Wei X, Patakas A, Leung BP, Mclnnes IB et al. Interleukin 27 attenuates collagen-induced arthritis. Ann Rheum Dis 2008; 67: 1474-1479.

10 Wong CK, Chen da P, Tam LS, Li EK, Yin YB, Lam CW. Effects of inflammatory cytokine IL-27 on the activation of fibroblast-like synoviocytes in rheumatoid arthritis. Arthritis Res Ther 2010; 12: R129.

11 Hirota K, Yoshitomi H, Hashimoto M, Maeda S, Teradaira S, Sugimoto N et al. Preferential recruitment of CCR6-expressing Th17 cells to inflamed joints via CCL20 in rheumatoid arthritis and its animal model. J Exp Med 2007; 204: 2803-2812.

12 Nakae S, Saijo S, Horai R, Sudo K, Mori S, Iwakura Y. IL-17 production from activated $T$ cells is required for the spontaneous development of destructive arthritis in mice deficient in IL-1 receptor antagonist. Proc NatI Acad Sci USA 2003; 100: 5986-5990.

13 Goldberg R, Wildbaum G, Zohar Y, Maor G, Karin N. Suppression of ongoing adjuvant-induced arthritis by neutralizing the function of the p28 subunit of IL-27. J Immunol 2004; 173: 1171-1178.

14 Park JS, Jung YO, Oh HJ, Park SJ, Heo YJ, Kang CM et al. Interleukin-27 suppresses osteoclastogenesis via induction of interferon-gamma. Immunology 2012; 137: 326-335.

15 Zheng XX, Steele AW, Nickerson PW, Steurer W, Steiger J, Strom TB. Administration of noncytolytic IL-10/Fc in murine models of lipopolysaccharide-induced septic shock and allogeneic islet transplantation. J Immunol 1995; 154: 5590-5600.

$16 \mathrm{Ha}$ SJ, Jeon BY, Kim SC, Kim DJ, Song MK, Sung YC et al. Therapeutic effect of DNA vaccines combined with chemotherapy in a latent infection 
model after aerosol infection of mice with Mycobacterium tuberculosis. Gene Therapy 2003; 10: 1592-1599.

17 Bettan M, Emmanuel F, Darteil R, Caillaud JM, Soubrier F, Delaere P et al. High-level protein secretion into blood circulation after electric pulsemediated gene transfer into skeletal muscle. Mol Ther 2000; 2: 204-210.

18 Park MK, Park JS, Cho ML, Oh HJ, Heo YJ, Woo YJ et al. Grape seed proanthocyanidin extract (GSPE) differentially regulates Foxp3 $(+)$ regulatory and IL-17( + ) pathogenic T cell in autoimmune arthritis. Immunol Lett 2011; 135: 50-58.

19 Wing K, Onishi Y, Prieto-Martin P, Yamaguchi T, Miyara M, Fehervari Z et al. CTLA-4 control over Foxp3 + regulatory $T$ cell function. Science 2008; 322: 271-275.

20 Francisco LM, Salinas VH, Brown KE, Vanguri VK, Freeman GJ, Kuchroo VK et al. PD-L1 regulates the development, maintenance, and function of induced regulatory T cells. J Exp Med 2009; 206: 3015-3029.

21 Schaer DA, Murphy JT, Wolchok JD. Modulation of GITR for cancer immunotherapy. Curr Opin Immunol 2012; 24: 217-224.

22 Pickens SR, Chamberlain ND, Volin MV, Mandelin AM II, Agrawal H, Matsui $M$ et al. Local expression of interleukin-27 ameliorates collageninduced arthritis. Arthritis Rheum 2011; 63: 2289-2298.

23 Park JS, Jung YO, Oh HJ, Park SJ, Heo YJ, Kang CM et al. Interleukin-27 suppresses osteoclastogenesis via induction of interferon-gamma. Immunology 2012; 137: 326-335.

24 Stumhofer JS, Laurence A, Wilson EH, Huang E, Tato CM, Johnson LM et al. Interleukin 27 negatively regulates the development of interleukin 17-producing $T$ helper cells during chronic inflammation of the central nervous system. Nat Immunol 2006; 7: 937-945.

25 Batten M, Li J, Yi S, Kljavin NM, Danilenko DM, Lucas S et al. Interleukin 27 limits autoimmune encephalomyelitis by suppressing the development of interleukin 17-producing T cells. Nat Immunol 2006; 7: 929-936.

26 Hall AO, Beiting DP, Tato C, John B, Oldenhove G, Lombana CG et al. The cytokines interleukin 27 and interferon-gamma promote distinct Treg cell populations required to limit infection-induced pathology. Immunity 2012; 37: 511-523.

27 Shibata S, Tada Y, Asano Y, Yanaba K, Sugaya M, Kadono T et al. IL-27 activates Th1-mediated responses in imiquimod-induced psoriasis-like skin lesions. J Invest Dermatol 2013; 133: 479-488.

28 Langrish CL, Chen Y, Blumenschein WM, Mattson J, Basham B, Sedgwick JD et al. IL-23 drives a pathogenic $T$ cell population that induces autoimmune inflammation. J Exp Med 2005; 201: 233-240.

29 Harrington LE, Hatton RD, Mangan PR, Turner H, Murphy TL, Murphy KM et al. Interleukin 17-producing CD4 + effector T cells develop via a lineage distinct from the T helper type 1 and 2 lineages. Nat Immunol 2005; 6: $1123-1132$.

30 Park H, Li Z, Yang XO, Chang SH, Nurieva R, Wang YH et al. A distinct lineage of $C D 4 T$ cells regulates tissue inflammation by producing interleukin 17. Nat Immunol 2005; 6: 1133-1141.

31 Acosta-Rodriguez EV, Rivino L, Geginat J, Jarrossay D, Gattorno M, Lanzavecchia A et al. Surface phenotype and antigenic specificity of human interleukin 17-producing $\mathrm{T}$ helper memory cells. Nat Immunol 2007; 8: 639-646.

32 Yang L, Anderson DE, Baecher-Allan C, Hastings WD, Bettelli E, Oukka M et al. IL-21 and TGF-beta are required for differentiation of human $\mathrm{T}(\mathrm{H}) 17$ cells. Nature 2008; 454: 350-352.

33 Manel N, Unutmaz D, Littman DR. The differentiation of human $\mathrm{T}(\mathrm{H})-17$ cells requires transforming growth factor-beta and induction of the nuclear receptor RORgammat. Nat Immunol 2008; 9: 641-649.

34 Lubberts E. IL-17/Th17 targeting: on the road to prevent chronic destructive arthritis? Cytokine 2008; 41: 84-91.

35 Lubberts E, Koenders MI, van den Berg WB. The role of T-cell interleukin17 in conducting destructive arthritis: lessons from animal models. Arthritis Res Ther 2005; 7: 29-37.
36 Waldburger JM, Firestein GS. Garden of therapeutic delights: new targets in rheumatic diseases. Arthritis Res Ther 2009; 11: 206.

37 Lubberts E, Joosten LA, Oppers B, van den Bersselaar L, Coenen-de Roo CJ, Kolls JK et al. IL-1-independent role of IL-17 in synovial inflammation and joint destruction during collagen-induced arthritis. J Immunol 2001; 167: 1004-1013.

38 Genovese MC, Van den Bosch F, Roberson SA, Bojin S, Biagini IM, Ryan P et al. LY2439821, a humanized anti-interleukin-17 monoclonal antibody, in the treatment of patients with rheumatoid arthritis: a phase I randomized, double-blind, placebo-controlled, proof-of-concept study. Arthritis Rheum 2010; 62: 929-939.

39 Sakaguchi S. Animal models of autoimmunity and their relevance to human diseases. Curr Opin Immunol 2000; 12: 684-690.

40 Morgan ME, Sutmuller RP, Witteveen HJ, van Duivenvoorde LM, Zanelli E, Melief CJ et al. CD25 + cell depletion hastens the onset of severe disease in collagen-induced arthritis. Arthritis Rheum 2003; 48: 1452-1460.

41 Cao D, Malmstrom V, Baecher-Allan C, Hafler D, Klareskog L, Trollmo C. Isolation and functional characterization of regulatory CD25brightCD4 + T cells from the target organ of patients with rheumatoid arthritis. Eur $J$ Immunol 2003; 33: 215-223.

42 Mottonen M, Heikkinen J, Mustonen L, Isomaki P, Luukkainen R, Lassila O. CD4 + CD25 + T cells with the phenotypic and functional characteristics of regulatory $\mathrm{T}$ cells are enriched in the synovial fluid of patients with rheumatoid arthritis. Clin Exp Immunol 2005; 140: 360-367.

43 Ehrenstein MR, Evans JG, Singh A, Moore S, Warnes G, Isenberg DA et al. Compromised function of regulatory $T$ cells in rheumatoid arthritis and reversal by anti-TNFalpha therapy. J Exp Med 2004; 200: 277-285.

44 Flores-Borja F, Jury EC, Mauri C, Ehrenstein MR. Defects in CTLA-4 are associated with abnormal regulatory T cell function in rheumatoid arthritis. Proc Natl Acad Sci USA 2008; 105: 19396-19401.

45 Nadkarni S, Mauri C, Ehrenstein MR. Anti-TNF-alpha therapy induces a distinct regulatory $T$ cell population in patients with rheumatoid arthritis via TGF-beta. J Exp Med 2007; 204: 33-39.

46 Valencia X, Stephens G, Goldbach-Mansky R, Wilson M, Shevach EM, Lipsky PE. TNF downmodulates the function of human CD4 + CD25hi T-regulatory cells. Blood 2006; 108: 253-261.

47 Read S, Malmstrom V, Powrie F. Cytotoxic T lymphocyte-associated antigen 4 plays an essential role in the function of $\operatorname{CD25}(+) \operatorname{CD} 4(+)$ regulatory cells that control intestinal inflammation. J Exp Med 2000; 192: 295-302.

48 Shimizu J, Yamazaki S, Takahashi T, Ishida Y, Sakaguchi S. Stimulation of CD25(+)CD4(+) regulatory T cells through GITR breaks immunological self-tolerance. Nat Immunol 2002; 3: 135-142.

49 Bodhankar S, Vandenbark AA, Offner H. Oestrogen treatment of experimental autoimmune encephalomyelitis requires 17 beta-oestradiol-receptor-positive B cells that up-regulate PD-1 on CD4 + Foxp3 + regulatory T cells. Immunology 2012; 137: 282-293.

50 Nishimura H, Nose M, Hiai H, Minato N, Honjo T. Development of lupus-like autoimmune diseases by disruption of the PD-1 gene encoding an ITIM motif-carrying immunoreceptor. Immunity 1999; 11: 141-151.

51 Tang Q, Boden EK, Henriksen KJ, Bour-Jordan H, Bi M, Bluestone JA Distinct roles of CTLA-4 and TGF-beta in CD4 + CD25 + regulatory T cell function. Eur J Immunol 2004; 34: 2996-3005.

(i) () $€$ This work is licensed under a Creative Commons Attribution-NonCommercial-NoDerivs 3.0 Unported License. To view a copy of this license, visit http:// creativecommons.org/licenses/by-nc-nd/3.0/ 